\title{
Chlorophyll Formation in Euglena gracilis var. bacillaris: Interference by Vitamin Analogues
}

\author{
By P. J. DUBASH AND D. V. REGE \\ Department of Chemical Technology, University of Bombay, \\ Matunga, Bombay I9, India
}

(Accepted for publication 22 September 1967)

\section{SUMMARY}

The formation of chlorophyll in non-proliferating etiolated cells of Euglena gracilis var. bacillaris is inhibited by some antimetabolite analogues of vitamins. The cell size and cell mass of light-grown euglenas is considerably increased in vitamin B I2 deficiency. The inhibitory effect of 2,6-diaminopurine on chlorophyll formation in non-proliferating euglenas was not annulled by vitamin B I2; 6-mercaptopurine, sulphanilamide and benzimidazole were without effect. Isoniazide inhibition is not reversed by niacin; surprisingly, the vitamin itself is markedly inhibitory. The inhibitory effect of niacin, however, is prevented by pyridine-3-sulphonate. Niacin and its analogues were more inhibitory to growth in the dark than in the light. The inhibition of growth by niacin in the light is annulled appreciably by either glucose or pyruvate, or an overwhelming concentration of vitamin B I2. Aminopterin, desoxypyridoxine and 2-chloro-p-aminobenzoic acid do not have any effect on chlorophyll synthesis in non-proliferating euglenas; the last mentioned inhibits the growth of the alga more in the dark than in the light. Thiamine deficiency inhibits growth; such sub-optimally grown euglenas also synthesize less chlorophyll per cell on subsequent illumination under non-proliferation conditions.

The negative growth response of light-grown Euglena gracilis var. bacillaris to niacin suggests a microbiological method of estimating this vitamin in biological materials and pharmaceutical preparations up to concentrations of $70 \mu \mathrm{g} . / \mathrm{ml}$. in the growth medium. The $50 \%$ inhibition level of niacin in the light is $46 \mu \mathrm{g} . / \mathrm{ml}$.

\section{INTRODUCTION}

Exposure of dark-grown euglenas to light in a non-proliferation medium brings about the synthesis of chlorophyll with several associated changes. The formation of chlorophyll is inhibited by antimetabolite analogues of purines, pyrimidines and amino acids (Dubash \& Rege, 1967a). No direct evidence of the involvement of vitamins during the pigment formation in dark-grown non-proliferating euglenas is available; such an apparent independence may mean synthesis of these during growth irrespective of illumination. The effect of antimetabolite analogues of vitamins was therefore studied with a view to explore the possible association of vitamins with the synthesis of chlorophyll.

\section{METHODS}

Euglena gracilis var. bacillaris was grown, harvested and illuminated under nonproliferating conditions as described earlier (Dubash \& Rege, I967a,b). Measurement 
of growth, chlorophyll and cell numbers and all other experimental details have already been described. Dry weights of euglenas were determined by drying samples of the washed cell suspensions at $50-60^{\circ}$ for $12-14 \mathrm{hr}$.

\section{RESULTS}

Requirement of vitamin $B I 2$ and the effect of its antimetabolite analogues on growth and chlorophyll synthesis

Euglena gracilis var. bacillaris exhibits a unique requirement of an exogenous supply of vitamin B I2 (Hutner \& Provasoli, 1964); it was of interest to check whether this vitamin is required for chlorophyll synthesis or for other metabolic purposes.

Organisms grown under conditions varied with respect to vitamin B I2 showed variations in their chlorophyll content; sub-optimally grown organisms had a lower chlorophyll index per mg. dry wt. However, when the chlorophyll index was measured per organism, a slight enhancement was observed in the case of sub-optimally grown

Table I. Effect of vitamin B I2 deficiency on the synthesis of chlorophyll in Euglena gracilis var. bacillaris grown in the light

\begin{tabular}{|c|c|c|c|c|c|}
\hline \multirow{2}{*}{$\begin{array}{l}\text { Vitamin B I2 } \\
\text { in medium } \\
(\mu \mu \mathrm{g} . / \mathrm{ml} .)\end{array}$} & \multirow{2}{*}{$\begin{array}{c}\text { Dry wt } \\
\text { cell } \\
\text { suspension } \\
\text { (mg./ml.) }\end{array}$} & \multirow{2}{*}{$\begin{array}{l}\text { Cell count } \\
\text { of sus- } \\
\text { pension } \\
\left(\times 10^{6} / \mathrm{ml} .\right)\end{array}$} & \multicolumn{3}{|c|}{ O.D. at $660 \mathrm{~m} \mu$ of $10 \mathrm{ml}$. of methanol extract } \\
\hline & & & $\begin{array}{l}\text { Per ml. of } \\
\text { suspension }\end{array}$ & $\begin{array}{l}\text { Per mg. } \\
\text { cells }\end{array}$ & $\begin{array}{l}\text { Per } 10^{8} \\
\text { cells }\end{array}$ \\
\hline $\begin{array}{c}50 \\
\text { (Optimal) }\end{array}$ & $4 \cdot 36$ & $4 \cdot 42$ & 0.298 & 0.068 & 0.067 \\
\hline $\begin{array}{c}5 \\
\text { (Sub-optimal) }\end{array}$ & 3.23 & 1.25 & 0.096 & 0.029 & 0.077 \\
\hline
\end{tabular}

Table 2. Comparison of dry weights of Euglena gracilis var. bacillaris grown under different conditions of stress

\begin{tabular}{lcc}
\multicolumn{1}{c}{ Dry weight of } \\
Stress condition & $\begin{array}{c}\text { Dry wt of } \\
\text { (mg.) }\end{array}$ & $\begin{array}{c}\text { cells } \\
\text { treated cells }\end{array}$ \\
Control* & 0.99 & $\begin{array}{c}\text { Dry wt of } \\
\text { control cells }\end{array}$
\end{tabular}

* Euglena gracilis var. bacillaris grown in light in the glutamate-malate medium of Hutner, Provasoli, Schatz \& Haskins (1950).

$\dagger$ Readings of Buetow (I962): Euglena gracilis var. bacillaris (SM-LI), a streptomycin bleached mutant, grown in the dark with acetate as the sole carbon source in the medium of Cramer \& Myers (1952).

euglenas (Table I). This indicated an increase in size and cellular mass in vitamin B I2 deficiency. Buetow (1962) observed a similar decrease in the growth rate and increase in cellular mass of euglenas at lower incubation temperatures. Table 2 shows a comparison of the growth characteristics of the euglenas grown under different conditions of stress.

Although vitamin B 12 deficiency distorts cell metabolism and brings about these characteristic biochemical lesions during growth, results in Table 3 show that the 
vitamin plays no significant role during chlorophyll synthesis in non-proliferating organisms. The 2,6-diaminopurine inhibition of chlorophyll synthesis was not annulled to any extent by the presence of vitamin B 12. 6-Mercaptopurine, sulphanilamide and benzimidazole do not inhibit pigment synthesis.

Table 3. Effect of anti-metabolite analogues of vitamin B 12 on chlorophyll synthesis in non-proliferating etiolated organisms of Euglena gracilis var. bacillaris

\begin{tabular}{|c|c|c|}
\hline \multirow[b]{2}{*}{ Analogue } & \multicolumn{2}{|c|}{$\begin{array}{l}\text { Chlorophyll synthesized/cell/ } \\
\qquad 72 \mathrm{hr}(\%)\end{array}$} \\
\hline & Control & + I m $\mu \mathrm{g} . / \mathrm{ml}$. B I 2 \\
\hline $\begin{array}{l}\text { None } \\
\text { 2,6-Diaminopurine } \\
\text { 6-Mercaptopurine }\end{array}$ & $\begin{array}{l}100 \\
63 \cdot 9 \\
114.0\end{array}$ & $\begin{array}{r}100 \\
65 \cdot 0 \\
102 \cdot 8\end{array}$ \\
\hline Sulphanilamide & $102 \cdot 8$ & $95^{\circ} 2$ \\
\hline Benzimidazole & $97 \cdot 2$ & 80.5 \\
\hline
\end{tabular}

All analogues were added at a concentration of $1 \times 10^{-3} \mathrm{M}$ in the non-proliferation medium.

Table 4. Effect of antimetabolite analogues of vitamins on chlorophyll synthesis in non-proliferating etiolated organisms of Euglena gracilis var. bacillaris

$\begin{array}{cc}\begin{array}{c}\text { Concentration } \\ \text { in the non- } \\ \text { proliferation } \\ \text { medium }\end{array} & \begin{array}{c}\text { Inhibition of } \\ \text { greening }\end{array} \\ (\mu \mathrm{g} . / \mathrm{ml} .) & (\%) \\ & 0 \\ 2000 & 65 \cdot 5 \\ 200 & -11 \cdot 5 \\ 200 & -17 \cdot 1 \\ 20 & 10 \cdot 7 \\ 25 & 0 \\ 100 & 4.9\end{array}$

Table 5. Effect of anti-metabolite analogues of vitamins on the growth of Euglena gracilis var. bacillaris

\begin{tabular}{|c|c|c|c|}
\hline \multirow[b]{2}{*}{ Analogue } & \multirow{2}{*}{$\begin{array}{c}\text { Concentration } \\
\text { in the growth } \\
\text { medium } \\
(\mu \mathrm{g} . / \mathrm{ml} .)\end{array}$} & \multicolumn{2}{|c|}{ Inhibition of growth (\%) } \\
\hline & & Light & Dark \\
\hline None & . & 0 & 0 \\
\hline Niacinamide & 50 & $14 \cdot 0$ & $68 \cdot 5$ \\
\hline Isoniazide & 50 & $-6 \cdot 0$ & $14 \cdot 6$ \\
\hline 3-Acetylpyridine & 50 & $44: 5$ & $76 \cdot 0$ \\
\hline Pyridine-3-sulphonic acid & 50 & 0 & $22 \cdot 4$ \\
\hline Niacin & 50 & $62 \cdot 0$ & $75 \cdot 4$ \\
\hline Aminopterin & 20 & $3 \cdot \mathbf{I}$ & $1 \cdot 5$ \\
\hline 2-Chloro-p-amino benzoic acid & 25 & $54 \cdot 0$ & $63 \cdot 8$ \\
\hline
\end{tabular}

Effect of antimetabolite analogues of vitamins on chlorophyll synthesis and growth of Euglena gracilis var. bacillaris

Several other antimetabolite analogues of vitamins were tested for their effect on chlorophyll synthesis (Table 4) and growth (Table 5) of Euglena gracilis var. bacillaris. Aminopterin and desoxypyridoxine had little effect on chlorophyll synthesis in non- 
proliferating euglenas. Among the niacin derivatives tried, only isoniazide was inhibitory, whereas 3-acetylpyridine and pyridine-3-sulphonate were, in fact, stimulatory. However, these had varying effects on the growth of the euglenas. 2-Chloro-paminobenzoic acid and 3-acetyl pyridine were quite inhibitory to growth (Table 5) and more so in the dark, whereas pyridine-3-sulphonate and isoniazide were only inhibitory in the dark; aminopterin was ineffective. 2-Chloro-p-aminobenzoic acid and sulphanilamide had no effect on chlorophyll synthesis in non-proliferating euglenas although both inhibited growth.

\section{Effect of niacin derivatives}

In an attempt to study the possible annulment by the vitamin of the inhibition of chlorophyll synthesis by the antimetabolite analogues of niacin it was observed that $200 \mu \mathrm{g}$./ml. niacin was itself inhibitory to the synthesis of chlorophyll in non-proliferating euglenas. The effects of the various antimetabolite analogues of niacin along with this vitamin were therefore studied (Table 6). Figure I shows the negative growthresponse relationship between niacin concentration and growth of Euglena gracilis var. bacillaris.

Table 6. Effect of niacin and its anti-metabolite analogues on chlorophyll synthesis in non-proliferating etiolated organisms of Euglena gracilis var. bacillaris

\begin{tabular}{lcc}
\multicolumn{1}{c}{ Analogue } & $\begin{array}{c}\text { Concentration } \\
\text { in the non- } \\
\text { proliferation } \\
\text { medium } \\
(\mu \mathrm{g} . / \mathrm{ml} .)\end{array}$ & $\begin{array}{c}\text { Inhibition of } \\
\text { greening } \\
(\%)\end{array}$ \\
None &. & 0 \\
Niacin & 200 & $95 \cdot 6$ \\
Niacinamide & 2000 & 100 \\
Isoniazide & 2000 & $65 \cdot 6$ \\
3-Acetylpyridine & 200 & $-1 \mathrm{I} \cdot 5$ \\
Pyridine-3-sulphonic acid & 200 & $-17 \cdot \mathrm{I}$ \\
Niacin + 3-acetylpyridine &. & 100 \\
Niacin + pyridine-3-sulphonic acid &. & $-54 \cdot \mathrm{I}$
\end{tabular}

Both niacin and its amide were inhibitory to growth as well as chlorophyll synthesis (Tables 5,6 ). The growth inhibition with niacin was more marked in the dark than in the light as with other antimetabolite analogues of this vitamin. The inhibition of chlorophyll synthesis by niacin was completely overcome by pyridine-3-sulphonate (Table 6). Attempts to reverse this anomalous inhibition of growth by niacin have been met with only partial success. Table 7 shows a $50 \%$ annulment of the inhibition in the light by glucose or by a hundredfold increase in vitamin B 12 in the growth medium. There was, however, no annulment by these supplements in the dark.

Among the several Krebs-cycle intermediates tested for their effect on the niacin inhibition of growth, only pyruvate annulled the inhibition completely in light and partially in the dark. $\beta$-Glycerolphosphate and $\alpha$-ketoglutarate, however, could partially annul the niacin inhibition in the light but not in the dark. Succinate, citrate, malate and fumarate all aggravated the inhibition, particularly in the light. These results are given in Table 8. 


\section{Effect of thiamine}

The effect of thiamine deficiency on growth and chlorophyll synthesis in Euglena gracilis var. bacillaris is shown in Table 9. Thiamine-deficient organisms had a $15 \%$ lower potential for chlorophyll synthesis than normal organisms when they were illuminated under non-proliferating conditions.

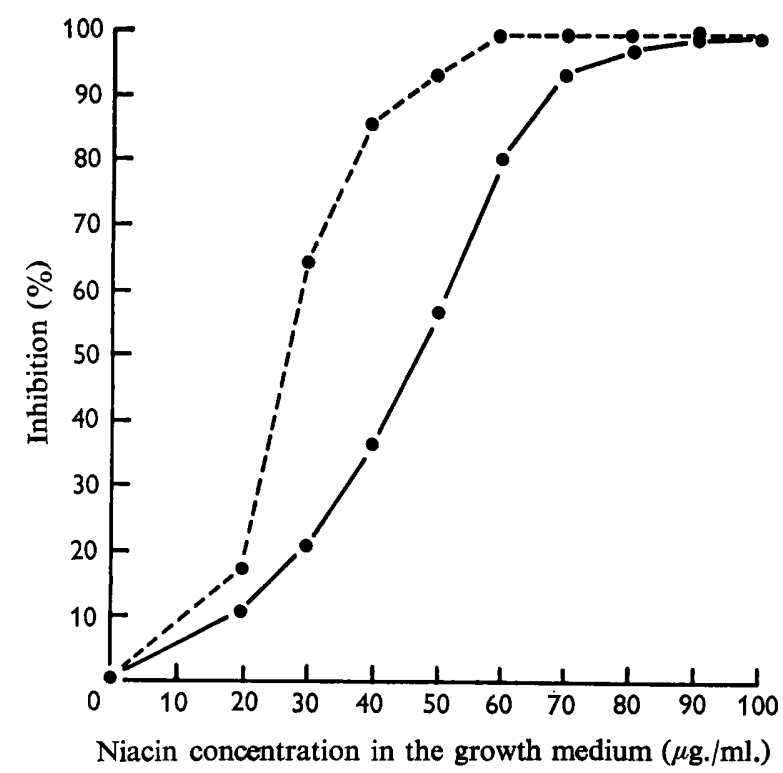

Fig. I. Effect of niacin on the growth of Euglena gracilis var. bacillaris in the light (-) and in the dark (---).

Table 7. Annulment of niacin growth inhibition of Euglena gracilis var. bacillaris with glucose and vitamin $B I 2$

\begin{tabular}{|c|c|c|c|c|c|c|}
\hline \multirow{3}{*}{$\begin{array}{c}\text { Vitamin B I } 2 \\
\text { in medium } \\
(\mu \mu \mathrm{g} . / \mathrm{ml} .)\end{array}$} & \multirow{3}{*}{$\begin{array}{l}\text { Niacin in } \\
\text { medium } \\
(46 \mu \mathrm{g} . / \mathrm{ml} .)\end{array}$} & \multirow{3}{*}{$\begin{array}{c}\text { Glucose } \\
\text { I } \%\end{array}$} & \multicolumn{2}{|c|}{ Growth in } & \multicolumn{2}{|c|}{$\begin{array}{l}\text { Inhibition of } \\
\text { growth (\%) }\end{array}$} \\
\hline & & & Light & Dark & & \\
\hline & & & \multicolumn{2}{|c|}{ (Klett) } & Light & Dark \\
\hline \multirow{4}{*}{50 (normal) } & - & - & 179 & . & 0 & . \\
\hline & - & + & I82 & 240 & 0 & 0 \\
\hline & + & - & 90 & . & 50 & . \\
\hline & + & + & I33 & 17 & 26 & 93 \\
\hline \multirow[t]{4}{*}{5000 (100-fold) } & - & - & 186 & . & 0 & . \\
\hline & + & - & 135 & . & 27 & $\cdot$ \\
\hline & - & + & $\cdot$ & 276 & . & 0 \\
\hline & + & + & . & 14 & . & 98 \\
\hline
\end{tabular}

Assay of niacin with Euglena gracilis var. baccillaris

The Euglena gracilis assay of vitamin B I 2 (Hutner, Bach \& Ross, 1956) owes its world-wide acceptance to its extreme sensitivity and its specificity for vitamin B I 2 (Hutner, I96I; Hutner \& Provasoli, 1964). The inhibitory effect of niacin on the photosynthetic growth of the euglenas was striking and offered an elegant method for 
assaying this vitamin microbiologically, taking advantage of the typical negativegrowth response curve which is shown in Fig. I. A linearity of response was shown for niacin concentrations up to $70 \mu \mathrm{g} . / \mathrm{ml}$. in the basal medium with a $50 \%$ inhibition level of the vitamin corresponding to $46 \mu \mathrm{g}$. $/ \mathrm{ml}$.

Table 8. Effect of Krebs cycle intermediates on the niacin inhibition of growth of Euglena gracilis var. bacillaris

\begin{tabular}{|c|c|c|}
\hline \multirow{2}{*}{$\begin{array}{c}\text { Krebs' cycle } \\
\text { acid added* ( } \% \text { \%) }\end{array}$} & \multicolumn{2}{|c|}{$\begin{array}{c}\text { Inhibition of growth with } \\
50 \mu \mathrm{g} . / \mathrm{ml} \text {. niacin (\%) }\end{array}$} \\
\hline & Light & Dark \\
\hline None & $65 \cdot 0$ & $83 \cdot 5$ \\
\hline Glucose & $33 \cdot 0$ & $96 \cdot 8$ \\
\hline Pyruvate & 0 & $45 \cdot 8$ \\
\hline Lactate & $59 \cdot 0$ & $87 \cdot 0$ \\
\hline Succinate & $84 \cdot 0$ & $84 \cdot 0$ \\
\hline Malate & $78 \cdot 0$ & $89 \cdot 5$ \\
\hline$\alpha$-Ketoglutarate & $43 \cdot 5$ & $92 \cdot 6$ \\
\hline$\beta$-Glycerophosphate & $37 \cdot 5$ & $87 \cdot 0$ \\
\hline Fumarate & $78 \cdot 8$ & $92 \cdot 3$ \\
\hline Citrate & $82 \cdot 2$ & $83 \cdot 1$ \\
\hline
\end{tabular}

* Additions of Krebs' intermediates were to the basal medium containing glutamate ( $(\%)$ and malate $(0 \cdot 2 \%)$ but without glucose.

Table 9. Thiamine requirement for growth and greening of Euglena gracilis var. bacillaris

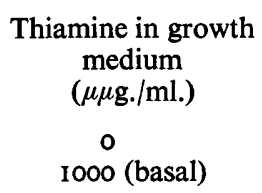

$\overbrace{\begin{array}{c}\text { Light } \\ 46 \cdot 0 \\ 0\end{array}}^{\text {Inhibition of growth (\%) }} \begin{gathered}\text { Dark } \\ 16 \cdot 0 \\ 0\end{gathered}$

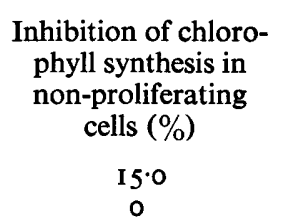

\section{DISCUSSION}

Although Venkataraman, Netrawali \& Sreenivasan (1965) suggested on the basis of incorporation of labelled ${ }^{14} \mathrm{C}$-formate that in DNA synthesis in Euglena gracilis var. bacillaris vitamin B I 2 has a greater role in the reduction of ribotides to deoxyribotides than in the reduction of formate to thymine methyl and that the vitamin B I2-dependent conversion of glutamate to $\beta$-methyl aspartate also contributed to thymine synthesis, its exact function in this organism still remains obscure. The role of vitamin B I2 in chlorophyll synthesis in euglena has not been explored. The dry weight of euglenas grown under conditions of vitamin B I 2 deficiency (Table 2) increased nearly $2 \frac{1}{2}$-fold as was the case of cultures grown at low temperatures(Buetow, I962). Gigantism was also apparent from results given in Table $\mathrm{I}$ on the basis of the chlorophyll index of the euglenas grown under sub-optimal vitamin B I 2 conditions. Both higher optimal temperatures and adequate vitamin B I 2 favour cell multiplication with a constant fragmentation of cellular material which prevents cell gigantism due to 'stagnation'. Cell enlargement has also been observed in the $z$ strain of Euglena gracilis (Epstein, Weiss, Causeley \& Bush, 1962) grown under sub-optimal vitamin B 12 conditions. The occurrence of a wide variation in cell size in response to anti-metabolites or metabolite 
deficiency has been reported by several workers (Beck, Hurlock \& Levin, 1960; Dubash \& Rege, $1967 b$; Epstein \& Weiss, I960 $a$; Ford \& Goulden, 1959; Rueckert \& Mueller, I960). Such varied size differentiation, along with the cellular accumulation of materials which render the organisms more opaque, must throw doubt on turbidimetric growth measurements. The vitamin B I2 assay with Euglena (Hutner et al. 1956) would, in the light of these experiments, be much more reliable if chlorophyll were taken as the index of growth rather than turbidity. The chlorophyll content of vitamin B I2-deficient organisms did not show such a wide variation (Table I). The strong inhibition by acetate and niacin (see Coelho, Dubash \& Rege, 1964) both of common occurrence in biological materials and pharmaceutical preparations and of growth stimulation by various Kreb's intermediates (Coelho et al. 1964) suggests need for caution when assaying vitamin B I2 or niacin with this alga. The graded negative growth response of photosynthetically growing Euglena gracilis var. bacillaris to the presence of niacin may prove useful for the assay of this vitamin in biological materials and pharmaceutical preparations.

Vitamin B I2, however, does not seem to have any significant role in chlorophyll synthesis in non-proliferating euglenas as is shown by the inability of vitamin B I2 to annul the inhibition by 2,6-diaminopurine. Although in growing euglenas, 6-mercaptopurine competes with vitamin B I2 presumably by interfering with dimethylbenzimidazol function rather than inducing purine deficiency (Epstein \& Timmis, 1963; Epstein $\&$ Weiss, $1960 a, b$ ), no inhibition of chlorophyll synthesis by this antimetabolite analogue was observed (Table 3). Similarly, benzimidazole (Epstein \& Timmis, 1963) and sulphanimide (Coelho, I966), reported to have an anti-BI2 activity for growth of Euglena, had no appreciable effect on greening. Epstein \& Timmis (I963) have shown both aminopterin and amethopterin to be inactive for Euglena. Aminopterin and desoxypyridoxine have also no effect on chlorophyll synthesis in non-proliferating etiolated euglenas on illumination (Tables 4, 5).

Both niacin and its amide are inhibitory for growth as well as chlorophyll synthesis in Euglena (Tables 5, 6) and these as well as the other anti-metabolite analogues of vitamins are more inhibitory in the dark than in the light. This indicates that these inhibit some system of general metabolic significance and do not obstruct some step in chlorophyll biosynthesis. The inhibition of chlorophyll synthesis by niacin is completely annulled by pyridine-3-sulphonate. It is clear from Tables 5 and 6 that other substitutions in the $\beta$-position of the pyridine ring lower the toxicity of the compound. A probable site of action of niacin and niacinamide would be for the TPN-requiring glyceraldehyde-3-phosphate dehydrogenase formed during chlorophyll synthesis (Fuller \& Gibbs, 1959; Brawerman \& Konigsberg, 1960). However, the niacin inhibition is exerted even in the dark when the euglenas are grown heterotrophically. Schopfer \& Keller (1951) have reversed the growth inhibition of Euglena gracilis caused by vitamin $\mathrm{K} 3$ with niacin or niacinamide and Frank et al. (1963) have overcome the thalidomide growth inhibition in this alga by niacin, niacinamide, NAD and vitamin K I. Although the latter authors have used a level of $\mathrm{Io} \mu \mathrm{g}$. $/ \mathrm{ml}$. niacin, they fail to report any inhibition of growth, whereas from Fig. I it is apparent that a $10 \%$ growth inhibition does occur at such a level. Frank et al. (1963), however, did find 6-amino-niacinamide to inhibit the growth of euglenas and reversed this effect with niacin. In the present case it is not only that a usual metabolite for other organisms is acting as an inhibitor, but that a normal antimetabolite ana- 
logue, pyridine-3-sulphonate, annuls this inhibition. The reversal, though partial, of niacin toxicity to the photosynthetic growth of euglenas by overwhelming concentrations of vitamin B I 2 may suggest that the former interferes in the utilization of the latter. It is also possible that vitamin B 12 is rendered unstable in the presence of niacin, particularly during sterilization of the medium at high temperatures; such examples of non-compatibility are known to occur in pharmaceutical preparations. The reversal by glucose of this niacin inhibition (Table 7 ) in the light may suggest that the inhibitor obstructs the photosynthetic pathway for eliciting energy; however, the more pronounced inhibition in the dark is inconsistent with this. The extremely high activity of pyruvate and $\alpha$-ketoglutarate, particularly in the light to prevent niacin inhibition (Table 7), may suggest that niacin interferes in some manner with the pyridine nucleotide metabolism. Both these $\alpha$-keto acids normally serve to produce the reduced NADH. It is quite possible that vitamin B I 2 may act by achieving the same end-results, as it is known that this vitamin serves in maintaining sulphydryl groups in the reduced form (Dubnoff \& Barton, 1956). A similar explanation had been given for the inhibitory effect of thalidomide (Frank et al. 1963), which is claimed to interfere at a point where niacin is converted to NAD or with the utilization of NAD and vitamin $\mathrm{K}$ in cellular oxidations. Mention must also be made at this point of another observation of Coelho (1966) that many glucose metabolites, particularly $\alpha$-ketoglutarate, spare the requirement of vitamin B 12 in this alga.

\section{REFERENCES}

BeCK, W. S., HURLock, B. \& LEVIN, M. (1960). Unbalanced growth in Lactobacillus leichmanii cultivated in excess and limiting vitamin B I 2 and deoxyriboside. Fedn. Proc. 19, 417.

BRAWERMAN, G. \& KonIGSBERG, N. (1960). On the formation of the TPN requiring glyceraldehyde-3phosphate dehydrogenase during the production of chloroplasts in Euglena gracilis. Biochim. biophys. Acta 43, 374.

BuEtow, D. E. (1962). Differential effects of temperature on the growth of Euglena gracilis. Expl. Cell Res. 27, 137.

Coelho, J. (1966). Studies in vitamin B I 2 metabolism. Thesis, Ph.D. (Tech.), University of Bombay.

Coelho, J., Dubash, P. J. \& Rege, D. V. (1964). Studies on the Euglena gracilis assay method for vitamin B I2. Bull. Natn. Inst. Sci. India, no. 25, p. 201.

CRAMER, M. \& MYERS, J. (1952). Growth and photosynthetic characteristics of Euglena gracilis. Arch. Mikrobiol. 17, 384.

DUBASH, P. J. \& REGE, D. V. (1967a). Chlorophyll formation in Euglena gracilis var. bacillaris. Interference by analogues of purines, pyrimidines and amino acids. J. gen. Microbiol. 48, 283.

Dubash, P. J. \& REGE, D. V. (1967b). Permanent bleaching of Euglena by $\mathbf{M g}^{2+}$ starvation. Biochim. biophys. Acta 136, 185.

Dubnoff, J. W. \& BarTon, E. (1956). Activation of protein sulphydryl groups by vitamin B I2. Archs. Biochem. Biophys. 62, 86.

Epstein, S. S. \& Timms, G. M. (1963). Simple antimetabolites of vitamin B 12. J. Protozool. ro, 63. Epstein, S. S. \& Weiss, J. B. (1960a). Measuring the size of isolated cells. Nature, Lond. 187, 46I.

Epstein, S. S. \& Weiss, J. B. (1960b). The extraction of pigments from Euglena gracilis. Biochem. J. 75, 247.

Epstein, S. S., Weiss, J. B., Causeley, D. \& Bush, P. (I962). Influence of vitamin B I2 on the size and growth of Euglena gracilis. J. Protozool. 9, 336.

ForD, J. E. \& GouldeN, J. D. S. (1959). The influence of vitamin B 12 on the growth rate and cell composition of the flagellate Ochromonas malhamensis. J. gen. Microbiol. 20, 267.

Frank, O., Baker, H., Ziffer, H., Aaronson, S., Hutner, S. H. \& Leevy, C. M. (1963). Metabolic deficiencies in protozoa induced by thalidomide. Science, N.Y. 139, I 10. 
FULLER, R. C. \& GIBBS, M. (1959). Intracellular and phylogenetic distribution of ribulose I : 5-diphosphate carboxylase and D-glyceraldehyde 3-phosphate dehydrogenase. Pl. Physiol. 34, 324.

HUTNER, S. H. (196I). Plant animals as experimental tools for growth studies. Bull. Torrey Bot. Club 88, 339.

Hutner, S. H. \& Provasoli, L. (1964). Nutrition of algae. A. Rev. Pl. Physiol. 15, 37.

HUtNeR, S. H., BACH, M. K. \& Ross, G. I. M. (1956). A sugar-containing basal medium for vitamin B I2-assay with Euglena: application to body fluids. J. Protozool. 3, IOI.

Hutner, S. H., Provasoli, L., Schatz, A. \& Haskins, C. (1950). Some approaches to the study of the role of metals in the metabolism of micro-organisms. Proc. Am. Phil. Soc. 94, 152.

Rueckert, R. R. \& Mueller, G. C. (1960). Studies on unbalanced growth in tissue culture. I. Induction and consequence of thymidine deficiency. Cancer Res. 20, 1584.

SCHOPFeR, W. H. \& KelleR, V. (195I). Action of vitamin $\mathrm{K}_{\mathbf{s}}$ and nicotinic acid on the green and colourless forms of Euglena gracilis. Bull. soc. chim biol. 33, 1253.

Venkataraman, S., Netrawali, M. S. \& Sreenivasan, A. (1965). The role of vitamin B i2 in the metabolism of Euglena gracilis var. bacillaris. Biochem. J. 96, 552. 